Original Paper http://ajol.info/index.php/ijbcs http://indexmedicus.afro.who.int

\title{
Preliminary assessment of bovine trypanosomiasis and its vectors in Santa, Bali and Bafut Sub-Divisions of the, North West Region, Cameroon
}

\author{
A. MAMOUDOU ${ }^{1 *}$, L.M. MBAKOU ${ }^{1}$, V. NGU NGWA. ${ }^{2}$, S. L. SEVIDZEM ${ }^{3}$, \\ A.P. ZOLI $^{1}$ et M.D. ACHUKWI ${ }^{4}$ \\ ${ }^{1}$ University of Ngaoundéré, School of Medicine and Veterinary Sciences, \\ Department of Parasitology and Parasitological Diseases, Ngaoundéré, Cameroon. \\ ${ }^{2}$ University of Ngaoundéré, School of Medicine and Veterinary Sciences, \\ Department of Microbiology and Infectious Diseases, Ngaoundéré, Cameroon. \\ ${ }^{3}$ Faculty of Science, Department of Animal Biology, University of Dschang BP 67 Dschang, Cameroon. \\ ${ }^{4}$ Veterinary Research Laboratory, Institute of Agricultural Research for Development, Wakwa Regional \\ Centre, BP 65 Ngaoundéré, Cameroon. \\ ${ }^{*}$ Corresponding author; E-mail: mamoudou.abdoulmoumini@yahoo.fr; Tel: Cell +237652415118;
}

\begin{abstract}
A cross-sectional study involving a questionnaire, parasitological examination of cattle and entomological prospection were conducted in the Mezam Division of Cameroon from December 2013 to May 2014 in two seasons for the first time. The objectives were to determine the prevalence of bovine trypanosomiais and its vectors. Peasant farmers $(n=95)$ were interviewed. Standard protocols for parasitological, hematocrit analysis as well as trypanosome identification were used. Acetone baited blue biconical traps $(n=5)$ were used for entomological survey. Questionnaire survey revealed that trypanosomiasis was one of the major health problems affecting animals and a hindrance to agricultural activities. The overall prevalence was $10.3 \%$ (31/301). Trypanosome species identified consisted of: T. vivax (58.1\%), T. brucei (25.8\%), T. congolense (9.6\%) and a mix infection (Trypanosoma congolense + Trypanosoma vivax) $(6.5 \%)$. Vector survey revealed highest fly catch in Bafut subdivision as compared to others with a significant difference $(\mathrm{P}<0.05)$. Fly types recorded included: Tabanus $125(71.4 \%)$, Stomoxys $31(17.7 \%)$ and Glossina morsitans submorsitans 19 (10.9\%). The overall Apparent Density (AD) was 1.53 fly per trap per day (f/t/d). Therefore, vector transmission and impact of the disease on production is alarming and should not be neglected. Control strategies have to be designed and implemented in Mezam Division in order to eradicate trypanosomiasis and its vectors.
\end{abstract}

(C) 2016 International Formulae Group. All rights reserved.

Keywords: Cattle, trypanosomiasis, Glossina, prevalence, Bafut.

\section{INTRODUCTION}

Trypanosomiasis is among the wellknown constraints to livestock production in Africa. It causes a serious and often fatal disease, mainly in rural poor communities and is rightfully considered as a root cause of poverty in the continent (Vreysen, 2006). However, 37countries are affected covering an area of about nine million square kilometers (Vreysen, 2006). It is estimated 
that about 50 million cattle are exposed to the disease and 35 million doses of trypanocides are used per year (Holmes et al., 2004). The direct and indirect annual losses are estimated at US\$ 4.5 billion (Hursey, 2001). Cameroon, considered as Africa in miniature, is one of the countries in the sub-Saharan Africa actively involved in livestock production. Several studies on the epidemiology of African Animal Trypanosomiasis (AAT) have already been conducted in the Northern part of the country and especially in the Adamaoua Region to define the disease situation (Achukwi and Musongong, 2009; Mamoudou et al., 2009; Tanenbe et al., 2010; Sevidzem, 2015).

The North-West Region of Cameroon is one of the potential regions as far as livestock production is concerned. With regards to its geographical landscape, altitude variation, temperature rainfall and climatic conditions may favour the existence of suitable habitats for tsetse and other biting flies. Up to date, there are no studies on the epidemiology and prevalence of AAT as well as its vectors across Mezam Division. This study is the first empirical assessment of the current status of AAT in the area. The major objectives of the study were to verify whether there is any correlation between the utilization of trypanocides and the existence of the disease, determine the prevalence of trypanosome species, identify the vectors and determine their Apparent Densities (AD).

\section{MATERIALS AND METHODS}

The study area

The study was conducted from December 2013 to May 2014 in Bali, Santa and Bafut Sub-Divisions in North-West Region of Cameroon (Figure 1). The Bafut, Bali and Santa Sub-Divisions in the Mezam Division were chosen for the study because these areas are mainly made up of Peasant farmers. Mezam Division has a surface area of about 17400 square kilometers and a population of above 850000 inhabitants. Administratively, Mezam Division has seven Sub-Divisions namely: Bamenda I, Bamenda II, Bamenda III, Bafut, Bali, Santa and Tubah
(MAOAR, 2013). The Division is made up of mainly the savannah vegetation having some natural forest reserves like the Bafut and Ngemba Forest Reserves. It comprises two distinct seasons: dry season which usually starts in mid-October and ends in mid-March while the rainy season begins in mid-March and ends in mid-October. However, this is unpredictable due to seasonal climatic changes. The mean annual rainfall of the Division ranges between 1884 and $2000 \mathrm{~mm}$ according to Mezam National Meteorological Service Agency, (MNMSA) MNMSA (2013). The Division is geographically located within the Western highlands of the country between latitude $5^{\circ} 40^{\prime}$ and $7^{\circ} 15^{`}$ North, and longitude $9^{\circ} 15^{\prime}$ and $11^{\circ} 5^{\prime}$ East with an altitude variation ranging from lower $(<900 \mathrm{~m})$, mid $(900-1500 \mathrm{~m})$ and to higher altitude $(>1500$ m) above sea level (MNMSA, 2013). The livestock population of the Division is estimated over 1318 cattle herds, over 22375 flocks of sheep, 46024 flocks of goat, 469 horse groups, over 23702 pig groups, over 1500 fish ponds and over 538369 poultry farms according to Mezam Agriculture Office Annual Report (MAOAR), MAOAR (2013).

\section{Study design}

This study was partitioned into three parts that is: a questionnaire, parasitological and entomological survey.

\section{Questionnaire survey}

Ninety-five (95) randomly scattered cattle breeders were interviewed from the representative habitats with the aid of a questionnaire, with objectives to investigate the presence of hematophagous flies, livestock constraints, bovine trypanosomiasis, livestock management, socio-economic status, herd composition, use and source of trypanocidal drugs.

\section{Study population and sampling method}

The study animals were local cattle breeds kept under smallholder extensive management system in the Mezam Division. A cross-sectional study design was used to determine the prevalence of bovine trypanosomiasis. A random sampling and purposive sampling methods were used to 
select the study animals and sites respectively. Age, sex, skin coat, breed, body condition score and previous history of treatment with trypanocidal drugs were considered. Age of animals was estimated with the help of farmers and confirmed through dentition. Animals were then divided in two categories: young ( $<3$ years) and adult ( $>3$ years). The sample size was determined based on the expected prevalence of $50 \%$ and absolute desired precision of $5 \%$ at $95 \%$ confidence level. The desired sample size was calculated using the standard formula as propounded by Thrusfield (2005).

\section{Body condition score, sample collection and examination}

Body condition scores were estimated according to semi-quantitative scale of Nicholson and Butterworth (1986) for evaluating the body condition of zebu cattle. The body condition of animals was recorded by classifying animals into three groups as "good" (3.5-5), "medium" (3) and "poor" (12.5) based on the appearance of ribs and dorsal spines. The emaciated animals were most often given priority during sampling.

A total of 301 blood samples were collected from jugular veins of cattle using sterile sharp needles directly into vacutainer tubes containing EDTA as anticoagulant. The tubes were further kept in a flask containing an ice-pack to maintain these blood samples in a cold chain and parasitological examination was done using a binocular Olympus microscope within six hours after sampling.

\section{Hematological and parasitological examination}

After centrifugation, Pack Cell Volume (PCV) for each blood sample was read immediately using a Hawskley microhematocrit reader. Trypanosome species were identified by characterizing motile species in wet films using the buffy coat technique (BCT) and morphological confirmation with the aid of Giemsa stained blood smears (Radostitis et al., 2007)

\section{Entomological survey}

Five acetone baited Biconical traps were deployed at drinking points and grazing areas of each of Bali top quarters, Saphery,
Babah, Njinki, Tchaboutchou, Munam and Ntchuobo and the GPS positions for each trap was recorded. The traps were separated $50 \mathrm{~m}$ apart and left in position for 3 consecutive days as described by Onyia (1976). Flies were collected from the traps each day before night fall. The apparent density of flies was calculated for each trap as described by Walle and Shearer (1997) and these flies further conserved in a solution of $70 \%$ methanol and $5 \%$ glycerine. The tsetse flies were identified to species level and the other biting flies to the genus level (Marquardt et al., 2000).

\section{Statistical analysis}

Data from entomological and parasitological surveys were analyzed using SPSS software version 16.0 program for analysis (SPSS, 2008). Two sample t-tests were utilized to compare the mean PCV values of infected and non-infected animals. Chi-square was used to compare host parameters. Differences between parameters were tested for significance at probability levels of $\mathrm{P}<0.05$.

\section{RESULTS \\ Questionnaire from cattle breeders}

Out of 95 cattle farmers interviewed, 39 indicated that the main livestock constraints included livestock diseases, shortage of grazing lands and drinking points during the dry season, transhumance problems, lack of veterinary assistance and scarcity of modern veterinary services. The main livestock diseases in order of importance were: babesiosis, trypanosomiasis ("Pial"), internal and external parasitosis, lumpy skin disease ("Bonlah"), foot and mouth disease ("Mboro") and contagious bovine pleuropneumonia. During the rainy season, animals shared common drinking points but different grazing fields during the dry season. Some had transhumance problems such as diseases encountered in new environments and death of cattle due to inadequacies in the transhumance areas. About $40 \%$ of the respondents were aware of the presence of hematophagous flies in the study area. 
Chemotherapy was the only approach for any disease control and trypanocides were administered to the animals by the herdsmen themselves, with clear drug abuse involved in $70 \%$ of treatments. Above $60 \%$ of respondents indicated that trypanocides were from nongovernmental sources, while just few got their supplies from government veterinary clinics. Some of them also indicated that they never had any specific treatment interval and most often, any abnormal signs could only draw their attention to use trypanocides. Diminazene aceturate (Berenil) "Ohly" and Isometamidium chloride (Samorine) "Bodhyi" were drugs administered to animals and the frequency of drug utilization strictly depended on the signs and symptoms revealed by animals such as lacrimation or progressive weight loss. Other drugs used alongside with trypanocides were: albendazol, pour-on formulations and oxytetracycline.

\section{Parasitological findings}

A total of 31 Buffy coat samples carried trypanosomes out of 301 blood samples examined, giving a prevalence of $10.3 \%$. Prevalence of trypanosomiasis was: $3.9 \%(\mathrm{n}=2), 0.0 \%(\mathrm{n}=0), 5.6 \%(\mathrm{n}=5)$, $6.1 \%(n=3)$ and $22.3 \%(n=21)$ for Saphery, Cedeno, Poultry station, Babah and Tchaboutchou Peasant associations respectively with no significant difference $(\mathrm{P}<$ 0.05) with sites (Table 1). The observed differences $\left(\mathrm{chi}^{2}\right.$-value) were significant $(\mathrm{P}<$ 0.05 ) (Table 1). Out of the $10.3 \%$ positive cattle examined for trypanosomes, $6 \%$ were positive for $T$. vivax, $1 \%$ for $T$. congolense, $2.7 \%$ for $T$. brucei and $0.6 \%$ for a mix infection ( $T$. congolense $+T$. vivax).

The prevalence of trypanosome infection was significantly $(\mathrm{P}<0.05)$ higher in females (13.4\%) than males (5.2\%). The prevalence of trypanosomiasis was $10.4 \%$ and $10.3 \%$ in young and adult cattle respectively with no statistical significant difference $(\mathrm{P}>$ 0.05) (Table 1). Body condition score in relation to trypanosome prevalence was: $8.3 \%, 7.6 \%$ and $15.0 \%$, in good, medium and poor score, respectively with no significant difference $(\mathrm{P}>0.05)$ (Table 1). Prevalence of trypanosome infections in various breeds of cattle was as follows: Gudali (7\%), Red Fulani (9.6\%), White Fulani $(12.7 \%)$ and Holstein breed $(0 \%)$, these observations were not significantly difference $(\mathrm{P}>0.05)$. Skin coat investigation revealed that trypanosome prevalence was: $14.9 \%, 11.0 \%$ and $5.6 \%$ for Black, Red and White skin coats respectively, with an observable non-significant difference (P >0.05) (Table 1).

\section{Hematological findings}

The PCV values of all examined cattle ranged from $21.60 \pm 6.07 \%$ to $27.26 \pm 2.46 \%$. The mean PCV of the infected $(23.39 \pm 3.748 \%)$ was lower than that for noninfected $(25.88 \pm 3.601 \%)$ cattle with a significant difference $(\mathrm{P}<0.05)$ ) Table 2). PCV decreased with increase log-parasitaemia (Figure 2).

\section{Entomological findings}

A total of 175 flies (potential vectors of bovine trypanosomiais) were caught with an overall apparent fly density of $1.53 \mathrm{f} / \mathrm{t} / \mathrm{d}$. Entomological prospection revealed that the degree of infestation defined by density of vectors was heterogonous with sites (Figure 2). Vector survey during the early rainy season was effected in Bafut Sub-Division, in the following quarters with their corresponding fly densities: Njinki (0.13 $\mathrm{f} / \mathrm{t} / \mathrm{d})$, Tchaboutchou (1.00 f/t/d), Munam (0.08 f/t/d) and Ntchuobo (0.04 f/t/d). Tchaboutchou was highly infested as seen from its density. During late dry season, sampling was effected in Bali and Santa. The situation of Bali Sub-Division was as follows: Bali top quarter $(0.05 \mathrm{f} / \mathrm{t} / \mathrm{d})$ and Saphery (0.16 f/t/d), with Saphery highly infested. Babah of Santa Sub-Divisions recorded 0.07 $\mathrm{f} / \mathrm{t} / \mathrm{d}$ during this season. Generally, the overall potential bovine trypanosomiais vectors density during the early rainy season was $1.17 \mathrm{f} / \mathrm{t} / \mathrm{d}$ and $0.28 \mathrm{f} / \mathrm{t} / \mathrm{d}$ during the late dry season. Seasonal densities revealed that infestation in these areas was topical in the early rainy season. 


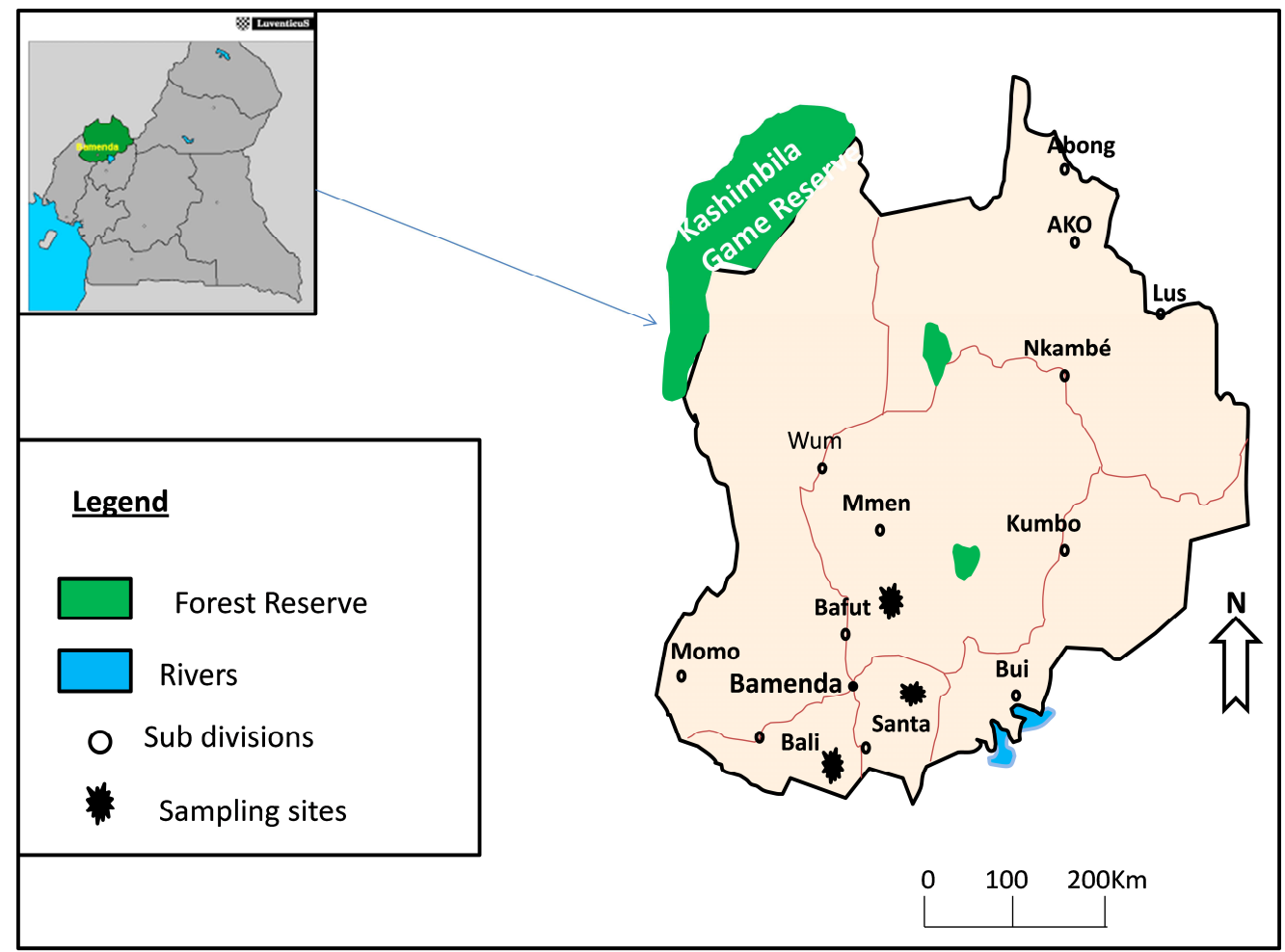

Source : Mfewou Abdoulay (2015)

Figure 1: Map of North-West Region of Cameroon showing the study area and sampling sites.

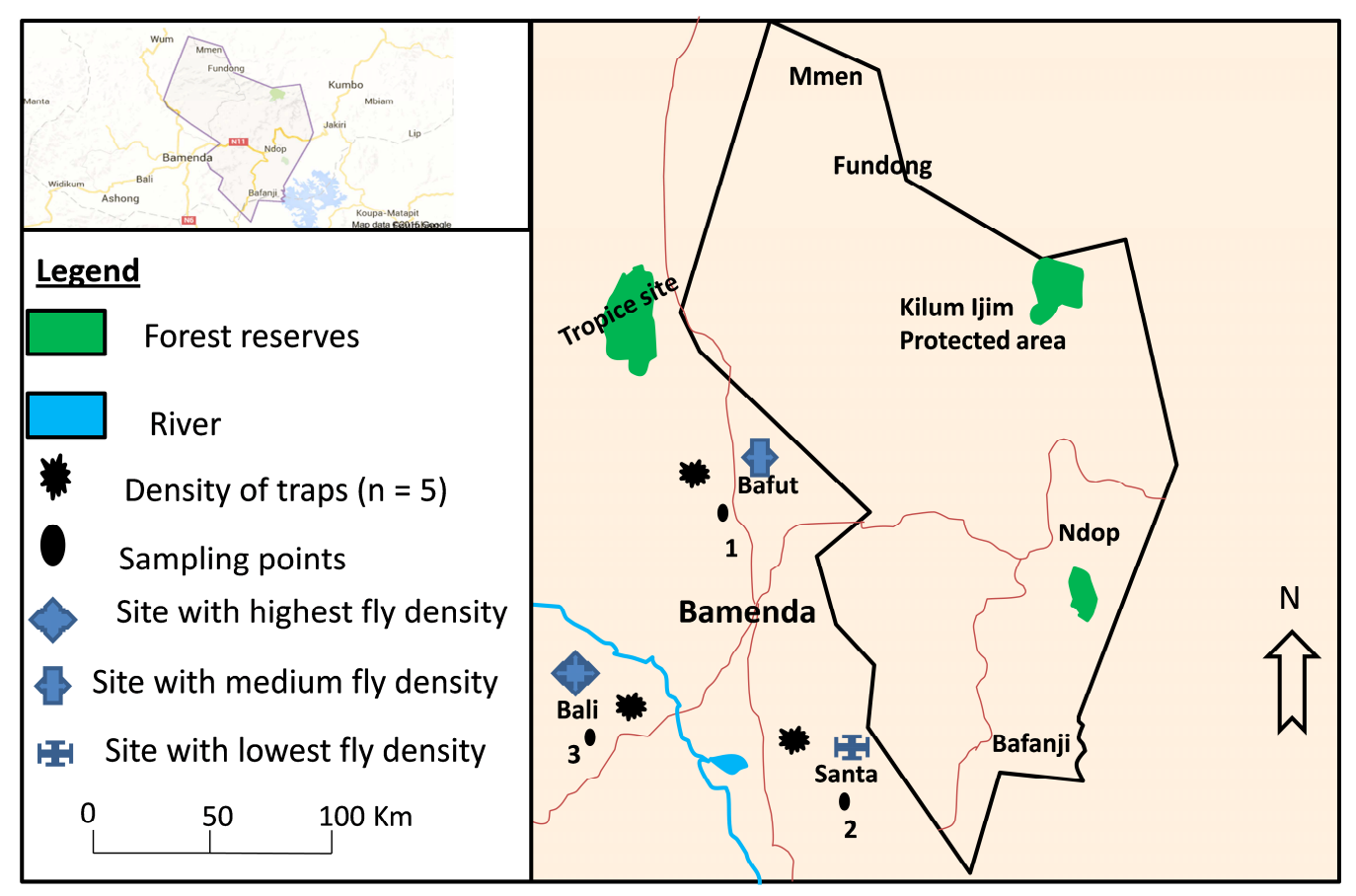

Source : Mfewou Abdoulay (2015)

Figure 2: Position of traps and vector densities with respect to site. 
A. MAMOUDOU et al. /Int. J. Biol. Chem. Sci. 10(1): 1-12, 2016

Table 1: Prevalence of bovine trypanosomiasis and its association with parameters.

\begin{tabular}{|c|c|c|c|c|c|}
\hline Examined Parameters & Number of examined animals & Number positive & Prevalence (\%) & $\mathbf{X}^{2}$ & P-value \\
\hline Sampling sites & & & & 0.007 & $\mathrm{p}<0.05$ \\
\hline Saphery & 51 & 2 & 3.9 & & \\
\hline Cedeno & 17 & 0 & 0 & & \\
\hline Poultry station & 90 & 5 & 5.6 & & \\
\hline Babah & 49 & 3 & 6.1 & & \\
\hline Tchaboutchou & 94 & 21 & 22.3 & & \\
\hline Total & 301 & 31 & 10.3 & & \\
\hline Sex & & & & 0.023 & $\mathrm{P}<0.05$ \\
\hline Male & 115 & 6 & 5.2 & & \\
\hline Female & 186 & 25 & 13.4 & & \\
\hline Total & 301 & 31 & 10.3 & & \\
\hline Age & & & & 0.974 & $\mathrm{p}>0.05$ \\
\hline Young ( $\leq 3$ years) & 106 & 11 & 10.4 & & \\
\hline Adult (>3years) & 195 & 20 & 10.3 & & \\
\hline Total & 301 & 31 & 10.3 & & \\
\hline BCS & & & & 0.142 & $\mathrm{p}>0.05$ \\
\hline Good & 36 & 3 & 8.3 & & \\
\hline Medium & 158 & 12 & 7.6 & & \\
\hline Poor & 107 & 16 & 15.0 & & \\
\hline Total & 301 & 31 & 10.3 & & \\
\hline Breed & & & & 0.142 & $p>0.05$ \\
\hline Gudali & 28 & 3 & 10.7 & & \\
\hline RedFulani & 208 & 20 & 9.6 & & \\
\hline White Fulani & 63 & 8 & 12.7 & & \\
\hline Holstein & 2 & 0 & 0 & & \\
\hline
\end{tabular}


A. MAMOUDOU et al. / Int. J. Biol. Chem. Sci. 10(1): 1-12, 2016

\begin{tabular}{lcccc} 
Total & 301 & 31 & 10.3 & \\
\hline Skin coat & & & & $0.153>0.05$ \\
Black & 67 & 10 & 14.9 & \\
Red & 145 & 16 & 11.0 & \\
White & 89 & 5 & 5.6 & \\
Total & 301 & 31 & 10.3 & \\
\hline \multicolumn{1}{c}{ BCS= Body Condition Score, $\mathrm{x}^{2}=$ chi-square test } & & & \\
\hline
\end{tabular}

Table 2: Prevalence of trypanosomosis and mean pack cell volume of examined animals.

\begin{tabular}{|c|c|c|c|c|c|c|c|c|c|}
\hline \multirow[t]{2}{*}{ Sampling sites } & \multirow{2}{*}{$\begin{array}{l}\text { Number } \\
\text { examined }\end{array}$} & \multicolumn{4}{|c|}{ Parasitological results } & \multirow[b]{2}{*}{ Mixed } & \multirow[b]{2}{*}{$\begin{array}{c}\text { Prevalence } \\
(\%)\end{array}$} & \multirow{2}{*}{$\begin{array}{c}\text { Mean PCV } \\
\text { of positive } \\
\text { animals }(\%)\end{array}$} & \multirow{2}{*}{$\begin{array}{c}\text { Mean PCV } \\
\text { of negative } \\
\text { animals (\%) }\end{array}$} \\
\hline & & Total positives & $\begin{array}{c}\text { Trypanosoma } \\
\text { vivax }\end{array}$ & $\begin{array}{c}\text { Trypanosoma } \\
\text { congolense }\end{array}$ & $\begin{array}{c}\text { Trypanosoma } \\
\text { brucei }\end{array}$ & & & & \\
\hline Saphery & 51 & 2 & $2(3.9 \%)$ & $0(0 \%)$ & $0(0 \%)$ & $0(0 \%)$ & 3.9 & $24.00 \pm 0.00$ & $24.67 \pm 3.42$ \\
\hline Cedeno & 17 & 0 & $0(0 \%)$ & $0(0 \%)$ & $0(0 \%)$ & $0(0 \%)$ & 0.0 & l & $26.06 \pm 4.51$ \\
\hline Poultry station & 90 & 5 & $5(5 \%)$ & $0(0 \%)$ & $0(0 \%)$ & $0(0 \%)$ & 5.6 & $21.60 \pm 6.07$ & $25.41 \pm 4.26$ \\
\hline Babah & 49 & 3 & $3(6.1 \%)$ & $0(0 \%)$ & $0(0 \%)$ & $0(0 \%)$ & 6.1 & $24.00 \pm 0.00$ & $25.78 \pm 3.02$ \\
\hline Tchaboutchou & 94 & 21 & $8(8.5 \%)$ & $3(3.2 \%)$ & $8(8.5 \%)$ & $2(2.1 \%)$ & 22.3 & $23.67 \pm 3.57$ & $27.26 \pm 2.46$ \\
\hline $\begin{array}{l}\text { Prevalence in } \\
\text { Mezam division }\end{array}$ & l & l & $5.81 \%$ & $0.97 \%$ & $2.59 \%$ & $0.65 \%$ & 10.3 & $23.39 \pm 3.75$ & $25.88 \pm 3.60$ \\
\hline
\end{tabular}


Table 3: Overall tsetse and other biting flies caught in different seasons.

\begin{tabular}{lccccc}
\hline \multirow{2}{*}{ Season } & Sampled sites & \multicolumn{4}{c}{ Number and type of different flies caught } \\
\cline { 3 - 6 } & & Total fly catch & Stomoxys & Tabanus & AD/f/t/d \\
\hline Late dry & Bali top quarters & 6 & $0(0.0 \%)$ & $6(100.0 \%)$ & 0.05 \\
season & Saphery & 18 & $6(33.3 \%)$ & $12(66.7 \%)$ & 0.16 \\
& Babah & 8 & $0(0.0 \%)$ & $7(87.5 \%)$ & 0.07 \\
\hline \multirow{2}{*}{ Early Rainy } & Njinki & 15 & $0(0.0 \%)$ & $0(0.0 \%)$ & 0.13 \\
season & Tchaboutchou & 115 & $19(16.5 \%)$ & $93(80.9 \%)$ & 1.00 \\
& Munam & 9 & $5(55.6 \%)$ & $4(44.4 \%)$ & 0.08 \\
& Ntchuobo & 4 & $1(25.0 \%)$ & $3(75.0 \%)$ & 0.04 \\
\hline Total & & 175 & $31(17.7 \%)$ & $125(71.4 \%)$ & 1.53 \\
\hline
\end{tabular}

\section{DISCUSSION}

The present study shows that the overall prevalence of trypanosomiasis in the study area was $10.3 \%$. This value was lower than that obtained by Tanenbe et al. (2010) for tsetse infested-uncleared pasture $(61.1 \%)$ and tsetse cleared areas $(24.7 \%)$ in the Adamaoua Plateau of North Cameroon. This observed difference could either be due to the low density of infected vectors or low rate of exposure of animals to infected tsetse bites in the study area. The study of Sevidzem (2015) revealed that variation in tsetse density appeared to be a factor among others contributing to the variation in the prevalence of trypanosomiasis. Prevalence of the disease was higher during the rainy season than dry season. This observation could be explained by the fact that during the rainy season, humidity and temperature increase tsetse lifespan and shorten the life cycle of trypanosomes (Kalu, 1995). A similar observation was made by Terzu (2004) in Ethiopia.

The majority of infections at the present sampling sites were due to $T$. vivax confirming the abundance of other potential haematophagous insect vectors other than tsetse flies such as Tabanus spp and Stomoxys spp. Abdalla et al. (2008) reported the noncyclical transmission of $T$. vivax infection has been detected in tsetse-free areas. Moreover, Bafut Forest Reserve contains wildlife such as antelopes which are generally accepted as reservoir hosts for $T$. vivax from which infections are transmitted across the wildlife/domestic interphase as reported by Kidamariam et al. (2000).

Statistical analysis revealed a significant difference between sampling sites. Peasant Farmers used chemo-prophylactic drugs most often, yet trypanosome-positive cases were recorded in their herds however this was not the case with Cedeno. It might be that Cedeno mostly fed their cattle on crop residues in confinement. This might have resulted in a decreased risk of infection, contrary to the Peasant Farmers who grazed their animals in bush lands exposing them to infected tsetse and other biting flies. Snow et al. (1996) reported that cattle which graze on bush land are more exposed to tsetse and other biting flies than cattle tethered within the village. Another reason could be that Cedeno cattle might have received trypanocidal drugs one month prior to sampling which might have been wrongly indicated by the cattle herdsmen.

There was significant difference in prevalence of cattle trypanosomiasis between age groups. The young animals are less infected because they graze at homestead until weaned off and are naturally protected to some extent by maternal antibodies (Leigh and Fayemi, 2011) Prevalence based on sex revealed that a greater proportion of females were infected than males, with a significant difference. This result is in consonance with that of Mersha et al. (2012) who also recorded a greater fraction of females infected than 
males, probable reason could be due to the small sample size of male as compared to female cattle in the study area and that livestock owners use male cattle for trade, usually keeping in the herd very few adult males.

Trypanosomiasis causes weight loss (cachexia) and emaciation is a characteristic sign of trypanosomiasis (Mamoudou et al., 2015). The high prevalence value observed for animals with poor body condition could be due to the chronic state of the disease that resulted to anemia and depletion of body condition. The degree of cattle susceptibility to trypanosomiasis and poor management of these animals might have led to a decrease in their immune status in tsetse infested zones in Mezam.

Prevalence was high in animals with black skin coat. However, there was no significant difference. Nevertheless, it has been shown that black skin coat serves as preferential color for tsetse and other biting flies during their blood meal (Girma et al., 2014). It could also be due to the ratio of positive animals to the total number of animals sampled. Black skin coats were proportionally higher than red and white skin coats.

Parasitological prevalence was highest for the White Fulani. However, there was no significant difference between breeds of cattle sampled. It has been shown that White Fulani is more tolerant to bovine trypanosomiasis than Gudali and other zebu types reason for their highest numbers in the Biological control of Tsetse flies (BICOT) area of Nigeria (R. Oluwafemi, 2009). The prevalence with respect to the Holstein breed was zero and this could either be associated to their relatively small number sampled during the study.

In the present study PCV results showed that there was a significant difference between cattle at different sampling sites. A higher percentage of anemic cattle were found in Saphery than in Cedeno. This could be associated with the management practice system. In Cedeno, cattle did not share a common drinking point or grazing field with other animals and this might have reduced their chances of being exposed to diseases (like tick infestation and helminthosis). Contrary to this, peasant animals shared a common drinking point. However, the herdsize of Cedeno was small, the care given to individual cattle was good and there was a lower risk of malnutrition. Most of Cedeno cattle were kept around the homestead, while the Peasant Farmers usually graze on bush land areas of the Valley, exposing them to infections which are liable to reduce PCV of most animals.

Other hematological findings also revealed a significant difference in PCV of both infected and non-infected cattle. Packed red cell Volume (PCV) is one of the most important indicators of trypanosomiasis in cattle (Van Den Bossche et al., 2006). Such a significant difference of PCV values between infected and non-infected cattle has already been reported by other authors (Van Den Bossche and Rowlands, 2001; Van Den Bossche et al., 2006) who observed that PCV of infected cattle decreased during infection period. This suggests that trypanosomiasis may be involved in lowering PCV of infected animals. The mean PCV values of young cattle were significantly higher than those of adults. It could be due to the fact that young animals develop superior erythropoietic responses during infection as compared to adults (Murray and Dexter, 1988).

The choice of microhaematocrit buffy coat was according to Luckins (1992) who classified the specificity and sensitivity of different diagnostic tests in decreasing order as follows: microhaematocrit> thick blood smear> wet film. Microhaematocrit buffy coat has advantage over other techniques in that in the field, this test is easily conducted and the general condition of the animals by PCV determination can be achieved (Mbahin et al., 2008).

The flies caught in Santa Sub-Division were Glossina and Tabanus but no Stomoxys. The significantly higher percentage of Tabanus could be attributed to more favorable climatic conditions for these flies. A thick 
forest in Babah could justify why at least a tsetse fly was caught. None was caught in Bali Sub-Division and this could be due to ecological imbalances as farmer's burn bushes during agricultural activities, resulting to migration of tsetse flies (Van Den Bossche et al., 1999). Fifteen Glossina morsitans submorsitans were caught from Njinki and three from Tchaboutchou. The absence of tsetse flies in Munam and Ntchuobo could be attributed to less favorable ecological conditions, which might have resulted to mortality of the flies as reported by Van Den Bossche et al. (1999). No Stomoxys were caught in Njinki and the total fly catch in Tchaboutchou was significantly higher as compared to Njinki, Munam and Ntchuobo. This significant difference could be due to their altitudinal preference. Similar result has already been reported by Langridge (1976) in Ethiopia.

It can be concluded that, out of 301 cattle examined, 31 were found positive for trypanosome infection giving an overall prevalence of $10.3 \%$. A correlation existed between the use of trypanocides and the existence of the disease since $40 \%$ of the respondents were aware of the existence of tsetse flies. The trypanosome species recorded were: Trypanosoma vivax, Trypanosoma brucei and a mix infection (T. vivax $+T$. congolense). Prevalence was highest for Trypanosoma vivax (58.06\%). From a total of 175 flies recorded, 19 were Glossina morsitans submorsitans, 125 Tabanus and 31 Stomoxys giving a total AD of $1.53 \mathrm{f} / \mathrm{t} / \mathrm{d}$. Identification of potential reservoirs of Trypanosoma vivax other than antelopes is recommended. Assessment of risk factors associated with the disease could be undertaken to know other reservoir hosts to gain more knowledge on the epidemiology of the disease.

\section{COMPETING INTEREST}

The authors declare that they have no competing interests.

\section{AUTHORS' CONTRIBUTIONS}

MA, ZAP and AMD conceived the study and coordinated field work; MA, MLM and SSL collected field data and helped in data analyses. MLM, MA and NNV interpreted the data and wrote the paper. All authors read and approved the final version.

\section{ACKNOWLEDGEMENTS}

The cattle breeders of Bali and Bafut Sub-Divisions are acknowledged for their cooperation and patience. We would also like to acknowledge the Department of Parasitology and Parasitological diseases of School of Veterinary Medicine and Sciences, University of Ngaoundéré for material support during field data collection.

\section{REFERENCES}

Abdalla MA, Bakhiet AO, Suliman SE. 2008. Seasonal prevalence of bovine trypanosomosis in Abu Bugar District, Central Sudan. Sudan J. Vet. Anim. Husbandry, 47: 1-5

Achukwi MD, Musongong GA. 2009. Trypanosomiasis in the Dayo/Namchi (Bos taurus) and zebu White Fulani (Bos indicus) cattle in Faro Division, North Cameroon. J. Applied Biosci., 15: 807-814.

Girma K, Meseret T, Tilahun, Z, Haimanot D, Firew L, Tadele K, Zelalem A. 2014. Prevalence of Bovine Trypanosomiasis, its Vector Density and Distribution in and Around Arbaminch, Gamogofa Zone, Ethiopia. Acta Parasitologica Globalis. 5(3): 169-176. DOI: 10.5829/idosi.org. 2014. 859.

Holmes PH, Eisler MC, Geerts S. 2004. Current Chemotherapy of Animal Trypanosomiasis, Maudlin I, Holmes, PH, Miles MA (eds). The Trypanosomiasis. CABI, UK; 431444.

Hursey BS. 2001. PAAT: The Programme against African Trypanosomiasis, 1p; poster issued to subscribers of Trends in Parasitology. 
Kalu AU, Uzoukwu M, Ikeme M. 1996. Prevalence of tsetse fly and ruminant trypanosomiasis in Katsina-Ala Local Government Area, Nigeria. Romanian Archives of Microbiology and Immunology, 55(4): 341-352.

Kidamariam K, Hadgu K, Sahle M. 2000. J. Ethiopian Vet. Ass., 4: 73-78.

Langridge WP. 1976. A tsetse and trypanosomiasis survey of Ethiopia. Ministry of Overseas Development, Ethiopia.

Leigh OO, Fayemi OE. 2011. The Prevalence of Trypanosomiasis in Female Wad Goats in Three Local Government Areas of Ibadan Nigeria. Global Vet., 6(1): 11-15.

Luckins AG. 1992. Methods for diagnosis of trypanosomiasis in livestock. World Anim. Rev. 70/71: 15.

Mamoudou A, Payne VK, Sevidzem SL. 2015. Hematocrit alterations and its effects in naturally infected indigenous cattle breeds due to Trypanosoma spp. on the Adamawa Plateau - Cameroon. Vet. World, 8(6): 813-818. Doi: 10.14202/vetworld.2015.813-818.

Mamoudou A, Zoli A, Tchoua P. 2009. Parasitological prevalence of bovine trypanosomiasis in the Faro and Deo division valley of the Adamaoua plateau Cameroon. Int. J. Biol. Chem. Sci., 3(5): 1192-1197.

MAOAR. 2013. Mezam Agricultural Office Annual Report, North-West, Cameroon.

Marquardt WC, Demaree RC, Grieue RB. 2000. Parasitology and Vector biology ( $2^{\text {nd }}$ edn). Academic Press: London.

MNMSA. 2013. Mezam National Meteorological Service Agency. Mezam Division, North West Region Cameroon.

Mbahin N, Zoli A, Mamoudou A, Tanenbe C, Abah S, Ghogomu RT, Nouala SF, Njeumi F. 2008. Parasitological prevalence of bovine trypanosomiasis in Faro and Deo division Cameroon, ten years after the tse-tse eradication campaign. Bull. Anim. Health Prod. Afr., 56: 289-297.

Mersha C, Chemirew A, Basaznew B. 2012. Hematopathology and haematological parametric alter-ations in indigenous cattle due to trypanosomiasis. Glob. Vet., 9(5): 546-551.

Murray M, Dexter TM. 1988. Anaemia in bovine African trypanosomiasis. Acta Tropica., 45: 389-432.

Nicholson MJ, Butterworth MH. 1986. A Guide to Condition Scoring of Zebu Cattle. ILCA: Addis Ababa Ethiopia. 212-235.

Oluwafemi RA. 2009. The Impact of African Animal Trypanosomiasisand Tsetse fly on the livelihood and well-being of cattle and their owners in the BICOT study area of Nigeria. The Internet $J$. Vet. Med., 5(2). DOI: 10.5580/2397.

Onyiah JA. 1997. African animal trypanosomiasis, an overview of the current status in Nigeria. Trop. Vet. J., 15: 1-16.

Radostits OM, Gay, CC, Hinchcliff KW, Constable PD. 2007. Veterinary Medicine, A textbook of the disease of cattle, sheep, goat, pigs and horses $\left(10^{\text {th }}\right.$ edn). Saunders Elsevier: London, New York; 2047-1533.

Sevidzem SL. 2015. Prevalence of bovine trypanosomiasis in the infested zone Alme of Faro and Deo Division, North Cameroon. MSc thesis, Dschang University, Dschang, p.36.

Snow WF, Wacher TJ, Rawling S. 1996. Observations on the prevalence of trypanosomiasis in small ruminants, equines and cattle, in relation to tsetse challenge, in Gambia. Vet. Parasitol. 66: $1-11$.

SPSS version 17.0. 2008. Computer Software, SPSS Inc., Chicago.

Tanenbe C, Gambo H, Musongong AG, Boris O, Achukwi MD. 2010. Prevalence of bovine trypanosomiasis in the Faro and Deo Division, and Vina in Cameroon: twenty years after fight against tsetse 
flies. Rev. Livestock. Vet. Med. Trop. Countries, 63(3-4): 63-69.

Terzu D. 2004. Seasonal dynamics of tsetse and trypanosomiasis in selected sites of Southern Nation, Nationalities and People Regional State, Ethiopia. M.Sc. thesis, Addis Ababa University, Faculty of Veterinary Medicine, Debre-Zeit, Ethiopia, P. 1 - 88.

Thrusfield M. 2005. Veterinary epidemiology $\left(2^{\text {nd }} E d n\right)$, Blackwell Science: Oxford; 117-198.

Van den Bossche J, Esterhuizen Nkuna R., Matjila T, Penzorn B, Geerts S, Marcotty T. 2006. An update of the bovine trypanosomiasis suitation at the edge of Hluhluwe iMfolozi park, Kwazulu-Natal Province,South Africa .Onderstepoort J. Vet. Res., 73: 77-79.

Van Den Bossche P, Mudenge D, Mubanga J, Norval A. 1999. The parasitological and serological prevalence of tsetse transmitted bovine trypanosomosis in the Eastern Caprivi (Caprivi District, Namibia). Onderstepoort J. Vet. Res., 66: 103-110.

Vreysen MJB, Saleh KM, Ali MY, Abdulla AM, Zhu Z, Juma KG, Dyck VA, Msangi AR, Mkonyi PA, Feldmann HU. 2000.Glossina austeni (Diptera: Glossinidae) eradicated on the island of Unguja, Zanzibar, using sterile insect technique. J. Econ. Ento., 93: $123-135$.

Walle R, Shearer D. 1997. Veterinary Entomology. Arthropod Ectoparasites of Veterinary Importance. Champman and Hall: London; 141 - 193.

Wellde BT, Hockmeyer WT, Kovatch RM, Bhogal, MS, Diggs CL. 1981.Trypanosoma congolense: natural and acquired resistance in the bovine. Exp. Parasitol., 52: 219-232. 